\title{
Climate change and financing adaptation by farmers in northern Nigeria
}

\author{
Terfa W. Abraham ${ }^{1 *}$ and William M. Fonta ${ }^{2}$
}

\author{
* Correspondence: \\ Lorenzcurve@yahoo.com \\ ${ }^{1}$ National Institute for Legislative \& \\ Democratic Studies (NILDS), No.1 \\ River Niger Street, Maitama, Abuja, \\ Nigeria \\ Full list of author information is \\ available at the end of the article
}

\begin{abstract}
This paper examines farmers' perceptions of their exposure to climate change in rural northern Nigeria. It also examines whether there is a significant relationship between the exposure of farmers to climate change and their need for financial access as an adaptation strategy. Questionnaires were administered to 320 respondents in rural communities in northern Nigeria. Descriptive analysis shows that rural farmers are affected by climate change through increased temperature, prolonged dry seasons, floods, and drought, which lead to low harvest and, in turn, low income. An estimate from a non-parametric test also shows a significant relationship between farmers' perceived exposure to climate change and their need for credit. Although the Spearman correlation results show a $63 \%$ association between exposure to climate change and the need for finance, $96 \%$ of those seeking credit to mitigate these impacts would be unable to do so due to financial exclusiveness. The paper recommends that the Central Bank of Nigeria should ensure that microfinance institutions refocus their products/services to those who need them the most in order to enhance access to financial resources and enable farmers to build resilience that will maximize post-harvest gains. Lastly, considering that climate change is a global phenomenon with local effects, perhaps the international community could support lending to smallholder farmers through central banks by insuring the loans that banks give to farmers towards financing climate change adaptation strategies.
\end{abstract}

Keywords: Rural households, Farm income, Climate change, Financial inclusion

\section{Introduction}

Farmers have always found ways to adapt to the impact of changing weather and climate conditions. Global climate and environmental changes, however, increase the scale at which farmers need to build and implement resilient strategies (see IISD 1995; von Braun 2002; Hess 2003; Ayers and Huq 2009; Aiello 2009; Akter and Fatema 2011; World Bank 2012; Kim 2013; Collier 2013; IFAD 2014). The literature on climate change and risk management strategies identifies several approaches to help farmers adapt to the impact of climate change; one example is access to credit (Botzen and van den Bergh 2008; Akter and Fatema 2011; WFP and IFAD 2011). While evidence of the effectiveness of access to credit as a poverty reduction strategy is mixed in the literature (see Diagne and Zeller 2001 and Zeller and Sharma 2002), others (e.g. Sorensen 2000; Pettengell 2010; World Bank 2012; Collier 2013) suggest that access to finance could have some effect as a climate change adaptation strategy.

(c) The Author(s). 2018 Open Access This article is distributed under the terms of the Creative Commons Attribution 4.0 International License (http://creativecommons.org/licenses/by/4.0/), which permits unrestricted use, distribution, and reproduction in any medium, provided you give appropriate credit to the original author(s) and the source, provide a link to the Creative Commons license, and indicate if changes were made. 
Climate change has been argued to have a worsening effect on the conditions of the poor (Nelson and Agbey 2005; Eriksen et al. 2007; CCAA 2010; Baumüller et al. 2011). Among the various adaptation strategies considered to mitigate the adverse effects of climate change on the poor, whether financial innovation aimed at increasing the access of households to financial services would enhance their adaptive capacity is not clearly established. A quote is taken from Agrawala and Carraro (2010), who provide insight into the relevance of assessing the role of financial inclusion in fostering adaptation to climate change:

"Much of the current policy debate on adaptation to climate change has focused on estimation of adaptation costs, ways to raise and to scale-up funding for adaptation, and the design of the international institutional architecture for adaptation financing. There is however little or no emphasis so far on actual delivery mechanisms to channel these resources at the sub-national level, particularly to target the poor who are also often the most vulnerable to the impacts of climate change. It is in this context that microfinance merits a closer look." (Agrawala and Carraro 2010:3).

In their assessment of farmers' perceptions of climate change in northern Nigeria, Farauta et al. (2011) identified various problems associated with climate change that include loss of crops and revenue, loss of forest resources, poor crop yield and quality, increase in weed infestation, increase in pest attack, and delay in planting time. Human activities such as bush burning, indiscriminate cutting of trees, and overgrazing of farmland by livestock, among others, were identified as factors that aggravate the exposure of farmers in northern Nigeria to the adverse effects of climate change. Building on this study, this paper examines the role access to credit could play in helping rural farm households in northern Nigeria mitigate the adverse effects of climate change on their primary occupation and the source of food supply to Africa's most populous country. Nigeria's population is approximately 182.2 million (2015 estimate), and the country has a population growth rate of $2.8 \%$. Available statistics further show that approximately $80.4 \%$ of the financially excluded population are rural dwellers, of which more than $70 \%$ practice land-use agriculture. However, this sector, which accounts for $44 \%$ of the GDP, only receives $2 \%$ of the total loans disbursed by commercial banks (CBN 2012). Therefore, the rationale for this paper is that since rural farm households in sub-Saharan Africa are vulnerable to climate change and are financially excluded, examining how financial inclusion can enhance their resilience to the increasing impact of climate change, especially in the Sudan savannah regions, would be important. Poverty is also highest in many developing countries that are also vulnerable to climate change as most failed to achieve the Millennium Development Goals (MDG) target of halving poverty by 2015. Thus, traditional methods of adaptation measures would be overstretched and access to technological innovation constrained due to limited or no access to financing.

Another justification for this paper is the goal of the Central Bank of Nigeria (CBN) and other stakeholders to implement a national financial inclusion strategy that will decrease the number of Nigerians that are excluded from financial services from $46.3 \%$ to $20.0 \%$ by 2020 and to increase the number that are included from 30\% in 2010 to $70 \%$ by 2020, as committed to in the Maya Declaration. The CBN (2012) noted that this goal will be achieved through a broad range of coordinated interventions that include the implementation of Credit Enhancement Schemes/Programs to empower micro, small, and medium-sized enterprises; these schemes/programs include the following: 
the Micro, Small, and Medium Enterprises Development Fund, of which 60\% is targeted at supporting the on-lending activities of microfinance banks and institutions to women enterprises and clients; implementation of the Nigerian Incentive-based Risk Sharing System for Agricultural Lending (NIRSAL); Entrepreneurship Development Centers (EDCs); Restructuring and Refinancing Facilities for SMEs; and the SME Credit Guarantee Scheme.

This paper, therefore, examines farmers' perceptions of their exposure to climate change in rural northern Nigeria. It also determines whether there is a significant relationship between the exposure of farmers to climate change and their need for financial access as an adaptation strategy. The paper contributes to the literature by testing the relationship between farmers' perceptions of their exposure to climate change and their need for credit to finance adaptation. A measure of the level of association is also provided in order to inform policy makers on the urgency of the situation.

\section{Literature review}

In a focus note for the Consultative Group to Assist the Poor (CGAP), Cull et al. (2014) conceptualized financial inclusion as a tool for achieving climate-resilient development. The report noted that global and national-level policy makers have embraced financial inclusion as an important development priority since 2009 when the G20 made it one of its pillars at the Pittsburgh Summit. Since then, more than 50 national-level policy-making and regulatory bodies have publicly committed to financial inclusion strategies for their countries (Cull et al, 2014). The report also noted that in October 2013, the World Bank Group postulated global universal access to basic transaction services as a goal and ability to use financial services as critical for achieving financial inclusion, improving the livelihoods of the poor, and reducing vulnerability.

Empirical evidence from the Overseas Development Institute (ODI) study (see Draper et al. 2011) also provided further evidence on access to finance as good for development. The study notes that cross-country regressions showed that economies with better developed financial systems experienced faster reductions in poverty levels and drops in income inequality (see Gross 2002). The Bank of Ghana, for instance, targeted the unbanked population using technological platforms and technology (the e-zwich biometric smartcard) for banks and other non-bank institutions to allow access to financial services by the unbanked in the context of overall payment system reform. Technologies such as mobile phones have also been argued to play a role in delivering financial inclusion [see Draper et al. (2011)]. Reviews conducted by Draper et al. (2011) and Ellis et al. (2010) provided further evidence using micro-level data in Kenya and Tanzania, which showed that access to financial services enabled households to invest in activities that were likely to contribute to their future income, whereas inadequate access constituted a major constraint. Aiello (2009) also argued that inadequate access to financial services limits the ability of vulnerable households to cope with and recover from adverse shocks, including those from global economic shocks, commodity price volatility, famine, and devastating natural disasters.

The United Nations Secretary-General's Special Advocate for Inclusive Finance for Development (UNSGSA) also uses inclusive finance to achieve food security and rural development (see UNSGSA 2013). The UNSGSA encourages universal access at a 
reasonable cost to a wide range of financial services, provided by diverse, responsible, and sustainable institutions. Through its special advocate, Her Majesty Queen Máxima of the Netherlands, UNSGSA also advocates that low-income clients and micro-, small-, and medium- sized enterprises (SMEs) need a variety of providers and products, such as savings, payments, credit, and insurance, to achieve rapid and sustainable development. Similar to the basic risk that accompanies weather insurance, the high risk of client over-indebtedness accompanies financial access as a tool for achieving resilient development. The UNSGSA report notes that while greater access to financial services has been beneficial, it has given rise to a new set of challenges, such as instances of the rapid expansion of consumer credit that result in a higher risk of client over-indebtedness; this questions the potential of financial services to contribute to the welfare of households.

\section{Empirical literature}

Agriculture in West Africa is largely rain-fed and is therefore vulnerable to floods and drought. With over $70 \%$ of the West African population depending on agriculture, weather shocks severely affect rural livelihoods (MeheRette 2009). As such, it has been argued in the literature that policies aiming to deliver financial services could serve as vehicle that is seen as providing a channel upon which risk mitigation strategies will strive (see Skees et al. 2006; Skees and Collier 2008). The literature on income and household welfare offers further insight into the quantitative link between climate change, financial exclusion, and poverty reduction, as inadequate savings and borrowing constraints could further expose households to economic hardship in developing countries (Amuedo-Dorantes and Pozo 2011). This is especially true for rural households that are dependent on agriculture for their livelihoods (De Sherbinin et al. 2008). Yang and Choi (2007) argued that, for vulnerable households with migrant members, a significant percentage of the decline in their income due to weather-related risks is replaced by inflows from migrant members. For a rural household case in the Philippines, Yang and Choi (2007) found that $60 \%$ of the declines in household income were replaced by remittance inflows from overseas. Though income smoothening is not always the main motive for sending remittances, as Amuedo-Dorantes and Pozo (2011) argued, Yang and Choi (2007) noted that remittances helps to smoothen the income of households in developing countries. Fonta et al. (2011) also argued that cash transfer from migrant members helps vulnerable households to build resilience to poverty and income inequality.

In the Augie community of Kebbi state, Nigeria, Agwu and Okhimamhe (2009) found that although rural farm households were already implementing numerous strategies to cope with the impact of climate change, which includes land degradation, they needed access to funds to strengthen their adaptive capacity. The study, which examined the impact of climate change from a gender perspective, also considered the case of a community in Niger state. Several studies and reports have argued that climate change has potentially grave consequences for the wellbeing and security of people across the world and have called for an integrated approach in addressing the challenges posed by climate change. Understanding how climate change interacts with socioeconomic systems and conceptualizing climate change as a social problem are equally important in 
the social sciences (see World Social Science Report 2013), as these would allow for political and socioeconomic measures to help cushion the effect on poor and vulnerable households.

Rural communities are highly underserved (Richter 2011). Traditionally, formal financial institutions have avoided or failed to offer sustainable services in rural areas (e.g., rural or agricultural development banks). Thus, informal or semiformal financial institutions, as well as alternative providers like traders or input suppliers, have become major providers of financial services. However, these informal providers often have weak institutional and managerial capacity, and operating in isolation from the financial system has let some of these providers charge steep interest rates. People living in rural areas may need access to financial services to purchase agriculture inputs; obtain veterinary services; maintain infrastructure; contract labor for planting/harvesting; transport goods to markets; make/receive payments; manage peak season incomes to cover expenses in low seasons; invest in education, shelter, and health; or deal with emergencies (see Richter 2011). Ejiogu and Ejiogu (2010) argued that microfinance, which plays a critical role in providing access to finance for vulnerable farm households, is not targeted at farm households that are vulnerable to the climate in Nigeria. Nigeria's existing funding mechanisms for climate change adaptation are inadequate. As contained in its National Adaptation Strategy and Plan of Action on Climate Change (NASPA-CCN) (see BNRCC 2011), Nigeria seeks to do the following to address its climate change adaptation funding gap: situate climate change adaptation financing within the broader context of national development financing and the development goals of Vision 2020; undertake a detailed financial needs assessment to properly determine the economic costs of climate change adaptation in Nigeria; review all multilateral mechanisms to finance climate change adaptation, and determine what capacities must be put in place to access and manage these funds; revise the National Fiscal Policy to incorporate the cost of climate change adaptation; develop an innovative, non-debt-creating national financing mechanism to support adaptation, raise the necessary funds, and manage those funds well; and ensure that climate financing policies and resource allocations are responsive to real needs. These are not bottom-up measures.

In the paper "Microfinance and Adaptation to Climate Change," Forcella (2013) argued that the proximity of MFIs to the clients could provide a comparative advantage to support local adaptation strategies. In addition, through microfinance, vulnerable groups can increase their resilience through asset accumulation and diversification of sources of income. While this channel of diversification is feasible for developed economies and farmers in urban centers, the author completely ignored the separability characteristic of a typical farm household model where farmers are both the consumers and producers. Other transmission channels through which microfinance can help households adapt as argued in the paper include the provision of non-productive loans, remittances, and information sharing. The link on remittances is also consistent with Fonta et al. (2011), who argued that household poverty reduces faster with remittances than without remittances in Nigeria. Forcella (2013) also identified tradeoffs that could be associated with microfinance and climate change adaptation strategies. These tradeoffs (such as microfinance being short term and climate change requiring long-term adaptation), however, did not contextualize the role microfinance will play in implementing adaptation strategies; rather, microfinance itself will be the end rather than the 
means to an end. Czura (2011) also argued that formal and informal credit have been identified as coping mechanisms for adverse income shocks for the case of flooding in northern India. That study also observed that most households only relied on informal financing sources such as family, friends, neighbors, and other relatives, indicating a lack of access to formal financing sources.

There is a connection between how farmers perceive their exposure to the negative effects of climate change and how they respond in building resilience to such exposure. Ochenje et al. (2016) examined the factors affecting farmers' perceptions of the effects of climate change on water resources in Kakamega County, Kenya. The focus was to understand, from the farmer's perspective, how they are affected by climate change and how that effect in turn constrains their access to water resources. Deteriorating water resources at the farm level as a result of climate change has led to decreased crop yields in sub-Saharan Africa and threatens food security, livelihoods, and water security. Using data collected from 159 farm households, an ordered probit model was employed to assess the factors affecting farmers' perceptions of climate change based on water resources. The results showed that farm size, distance to water sources, extension, access to climate change information through radio, and the wealth status of farmers significantly explained farmers' perceptions of climate change based on water resources. Roco et al. (2015) also used farmers' perceptions to examine the impact of climate change in Chile. They found that most farmers agreed that changes in temperature and precipitation patterns have occurred in their communities. Specifically, approximately $62 \%$ believed that average temperatures had increased, while $93 \%$ and $87 \%$ believed that precipitation had decreased and that droughts were more frequent, respectively. The authors concluded that implementing measures to cope with the changing climate would be necessary to minimize post-harvest losses and maximize farm income.

Munthali et al. (2016) assessed the perceptions of smallholder farmers with respect to climate variability and climate change adaptation in Bolero Community in northern Malawi. Survey data were collected using semi-structured interviews and focus group discussions from a sample size of 100 farmers. Using descriptive statistics and a chi-squared test for the analysis, they found that $76 \%$ of the farmers believed that temperatures had increased while $74 \%$ believed that rainfall in the community had decreased. The respondents also agreed that their increased exposure to these changes had affected their farming activity. Nevertheless, having access to credit and climate change information could motivate them to adopt coping and adaptation mechanisms to climate change and variability.

The findings from Ochenje et al. (2016), Munthali et al. (2016), and Roco et al. (2015) show that farmers' perceptions of how climate change affects their farming activities have a direct link with how they perceive the kind of adaptation they need. This deduction is also consistent with Elum et al. (2017), who examined how farmers' perceptions of climate change formed their adaptation strategies. They also examined the trend in climate parameters and the constraints on farmers. Primary data based on questionnaires were collected from 150 randomly sampled farmers in three provinces in South Africa from June to August 2015. Analysis of the farmers' perceptions of climate change showed that most farmers indicated that they had experienced higher temperatures, drought, and lower crop yields attributable to changing weather conditions over time. Other studies also report similar findings. For instance, Arshad et al. 
(2016) examined farmers' perceptions of climate change and the impact on farm productivity in rural Pakistan. Their study showed that farmers' adaptation strategies were highly influenced by the way they perceived the impact of climate change on the productivity of their farms. The increased need by farmers for extension services as well as financial services, they argued, were also found to be influenced by farmers' perceptions of climate change and its effects on their farm productivity.

\section{Theoretical literature}

The poverty growth inequality triangle theory provides the theoretical basis for the link between finance, inequality, and poverty reduction. Grammy and Assane (2006) summarize the poverty growth inequality hypothesis as follows:

"The theory states that, the extent and magnitude of absolute poverty depends on the growth of the mean level of real per capita income and the degree of inequality in the distribution of income. Thus the strategy of poverty reduction requires both growth and improved income distribution. Hence, growth is a process of sustained long-term increase in mean level of per capita income and improved distribution which would bring about greater equality in the distribution of income. At any given level of per capita income therefore, the more unequal the distribution of income, the greater is the incidence of poverty. It follows therefore that for any given pattern of income distribution, the lower the level of per capita income, the greater is the incidence of poverty."

However, the poverty growth inequality theory does not recognize the economic and noneconomic factors that could trigger a shock to the growth of sustained long-term mean income, especially for rural households where poverty is high and households that are dependent on rain-fed agriculture are vulnerable to the climate risks of floods or drought. The argument here is that development in the context of climate change requires rethinking the framework upon which existing policy measures are based to be cognizant of climate risks. This argument finds support in the literature. While noting that the relationship between financial development and economic growth has been well documented in King and Levine (1993), Beck et al. (2000), Demirgüç-Kunt and Maksimovic (1998), Beck et al. (2004), Levine (2005), Klapper et al. (2006), Demirgüç-Kunt and Levine (2008), and Ardic et al. (2011) pointed out that recent debates have been extended to include the notion of financial exclusion as a barrier to economic development and the need to build inclusive financial systems (see Beck et al. 2007). They cited Caskey et al. (2006), who used evidence from household data to argue that access to basic financial services, such as savings, payments, and credit, can make a substantial positive difference in improving the lives of poor people.

Another variant of this theory is the Kuznet hypothesis, which argues that the distribution effect of financial deepening is adverse for the poor at early stages but positive after a turning point (Beck et al. 2004). An earlier explanation by Greenwood and Jovanovic (1990) argued that there is an inverted U-shaped relationship between finance and economic development, such that financial intermediation creates income inequality at the early stage of financial development, as the rich would have access to resources to invest. Over time, therefore, financial access will expand to poorer 
segments of the population. The theory, however, has two major short comings: (1) it is time-insensitive to how long it would take for poor households to have access to finance, and (2) it does not allow for financial innovation that could be put in place to enhance the delivery of financial access to vulnerable deficit spending by microfinance institutions. There are three variants of the vulnerability framework linked to poverty and risk management: (a) vulnerability as expected poverty (VEP), (b) vulnerability as low expected utility (VEU), and (c) vulnerability as uninsured exposure to risk (VER). In the VEP framework, Chaudhuri et al. (2002) and Christiaensen and Subbarao (2001) defined vulnerability as the probability that a household will fall into poverty in the future such that the vulnerability of the household is the probability that the household level of consumption in the future will be below the consumption poverty line. Ligon and Schechter (2003) defined VEU with reference to the difference between the utility derived from some level of certainty-equivalent consumption, at and above which the household would not be considered vulnerable. Hence, this framework is analogous to a poverty line and the expected utility of consumption. As argued by Hoddinott and Quisumbing (2003), vulnerability as uninsured exposure to risk (VER) is similar to the VEP and VEU approaches in that it is concerned with assessing welfare and welfare losses in a world where some risks are at best partially insured. However, it differs from VEP measures in that it is backward looking; it is an ex post assessment of the extent to which a negative shock caused a welfare loss rather than an ex ante assessment of future poverty. It also differs from VEP and VEU measures in that there is no attempt to construct an aggregate measure of vulnerability; rather, the impact of shocks can be quantified to assist in identifying appropriate policy focus for the dependent variable used in Tesliuc and Lindert (2002) as consumption determined by covariates

There are several measures of income distribution, including the median share of income, calculation based on percentile distributions, the Lorenz curve, the Gini coefficient, Robin Hood index, Atkinson index, Thiel's entropy measure, and the coefficient of variation (Krol and Miedema 2009). Allison (1978) noted that choosing a standard income distribution measure is a choice between alternative definitions of inequality rather than a choice between alternative measures of a specific theoretical construct (see Krol and Miedema 2009). To measure inequality, therefore, we adopt the percentile distribution approach. This method divides the sample population into successive quintiles according to ascending income levels and then determines the proportion of income received by each income group using the ratio of incomes received by the top $20 \%$ and bottom $40 \%$. The choice of calculation of inequality using the quintile or percentile distribution is based on its strength of using readily available data to classify the distribution of income that captures direction and magnitude. It can also be used to compute the effectiveness of policies across income quintiles. The choice of this measure follows Krol and Miedema (2009), who argued in favor of using calculations based on quintile, decile, or percentile distributions as robust measures of inequality.

\section{Research methodology}

Nigeria constitutes over $50 \%$ of the West African population. Concentrated in the rural area, Nigeria's agricultural sector faces several challenges, including climate shocks and 
infrastructural and institutional constraints (see Kwanashie et al. 1998). This has consequences for over $60 \%$ of the nation's 184.264 million people (2015 estimate) who depend on the sector for livelihood. Available statistics show that 39.2 million or $46.3 \%$ of the total adult population of 84.7 million Nigerians (with women accounting for $54.4 \%$ ) are excluded from financial services. Approximately $80.4 \%$ of the financially excluded population resides in rural areas, of which more than $70 \%$ practice land-use agriculture. With the impact of climate change on rural livelihoods and land-use activities, households suffer from income shocks and are susceptible to falling further below the poverty line.

The specific communities studied (Fakai in Kebbi state and Rijau in Niger state) both fall within the Sudan savannah region of northern Nigeria. Another factor that influenced the choice of the study areas is poverty. While Niger state has the lowest poverty rate among the communities in the Sudan savannah region of Nigeria (less than 34\%), Kebbi state has one of the highest (more than 70\%). Drawing samples from both communities therefore eliminates response bias to the questionnaires. Using a questionnaire instrument, cross-sectional household data were randomly collected from two rural communities in the Sudan savannah areas of the northwest and north-central zones of Nigeria from 320 respondents. The sample size of each community in the study was calculated using the formula

$$
s=\frac{n}{1+\frac{n}{N}}
$$

where $N$ is the population of each state, and $n$ is the population in the study community. However, $n=\frac{Z^{2}[p(1-p)]}{D^{2}}$, could also be used to compute $n$. In that case, $p$ is the proportion of households in poverty, while Z2 and D2 are the confidence level and interval, respectively. Using figures from the 2006 Nigerian census for Fakai, $n=169,111$ and $N=3,256,541$. Meanwhile, $\mathrm{n}$ for Rijau is 166,053 and N is 3,850,249. Once obtained, $\mathrm{s}$ is divided by 1000 in population units. Hence, the sample size is 160.8 for Fakai and 159.2 for Rijau, yielding a total of 320 households to randomly sample in each community to make up the study area. The World Bank Group Financial Inclusion (Global Findex) database, launched in 2011 (see Demirguc-Kunt et al. 2015), which was freely downloaded, served as a template in the questionnaire design for this study. The primary data collected and used for this study can be downloaded from the WASCAL (West African Science Service Centre on Climate Change and Adapted Land Use) Geo portal following the link https://wascal-dataportal.org/ geonetwork/apps/search/.

Table 1 Kruskal-wallis equlity of Populations Rank Test

\begin{tabular}{lll}
\hline Community & Observation & Rank Sum \\
\hline Rijau & 160 & $26,057.5$ \\
Fakai & 160 & $25,302.5$ \\
Chi-squared & 0.208 with 1 d.f. & \\
Probability & 0.6482 & \\
Chi-square with ties & 0.213 with 1 d.f. & \\
Probability & 0.6446 & \\
\hline
\end{tabular}

Source: Author (STATA output) 
Table 2 Trend Test across Ordered Groups

\begin{tabular}{llll}
\hline Income Quintile & Score & Observation & Sum of ranks \\
\hline 1 & 1 & 59 & 1770 \\
2 & 2 & 64 & 5856 \\
3 & 3 & 66 & 10,329 \\
4 & 4 & 64 & 14,176 \\
5 & 5 & 67 & 19,229 \\
Z-score & 17.5 & & \\
Prob $>|z|$ & 0.000 & & \\
\hline
\end{tabular}

Source: Author (STATA output)

To achieve the first objective, descriptive analysis was used to examine the exposure of rural households to climate change. This includes the use of charts, tables, and percentages. Farauta et al. (2011) used similar methods to examine farmers' perceptions of climate change in northern Nigeria. For objective two, the statistical relationship between the exposure of rural farm households to climate change and their need for access to financial services as an adaptation strategy was examined using a chi-squared

Table 3 Description of Variables

\begin{tabular}{|c|c|c|}
\hline Variables Name & Description & Measurement Scale \\
\hline Gender & Gender of Respondent & $\begin{array}{l}\text { Male }=44.69 \% \\
\text { Female }=55.31 \%\end{array}$ \\
\hline Edu & Educational Qualification of Respondent & $\begin{array}{l}\text { Quranic/primary }=41.56 \% \text {, } \\
\text { Secondary/ post-secondary }= \\
58.44 \%\end{array}$ \\
\hline HH size & Household Size & $\begin{array}{l}\text { Max }=12 \\
\text { Minimum }=1 \\
\text { Mean }=5.59\end{array}$ \\
\hline Family Total Income (In a year) & Family Total Income (In Nigerian Naira) & $\begin{array}{l}\text { Max }=360,000 \\
\text { Minimum }=13,000 \\
\text { Mean }=91,372\end{array}$ \\
\hline$\%$ of Farm Income & & $77 \%$ \\
\hline$\%$ of Off-Farm Income & & $23 \%$ \\
\hline q13aSaveFI & Savings with Financial Institution & $\begin{array}{l}\text { Yes }=20.31 \% \\
\text { No }=79.69 \%\end{array}$ \\
\hline q13bSavesC & Membership of a Community Savings Clubs & $\begin{array}{l}\text { Yes }=66.56 \% \\
\text { No }=33.44 \%\end{array}$ \\
\hline q14aBFI & $\begin{array}{l}\text { Access to finance (borrowing) from Financial } \\
\text { Institution }\end{array}$ & $\begin{array}{l}\text { Yes }=80 \% \\
\text { No }=20 \%\end{array}$ \\
\hline q14cBFnF & $\begin{array}{l}\text { Access to finance (borrowing) from Family } \\
\text { and } \\
\text { Friends }\end{array}$ & $\begin{array}{l}\text { Yes }=87.5 \% \\
\text { No }=12.5 \%\end{array}$ \\
\hline InsureAgric & Traditional Crop Insurance & $\begin{array}{l}\text { Yes }=22.81 \% \\
\text { No }=77.19 \%\end{array}$ \\
\hline GovtAgPrgm & $\begin{array}{l}\text { Benefit to a Government Agricultural } \\
\text { Programme (fertilizers, irrigation, } \\
\text { improved seedlings, efforts } \\
\text { to mechanize farming) }\end{array}$ & $\begin{array}{l}\text { Yes }=36.56 \% \\
\text { No }=63.44 \%\end{array}$ \\
\hline $\begin{array}{l}\text { Dependent Variable } \\
\text { (Income Quintile) }\end{array}$ & $\begin{array}{l}\text { Poorest 20\%, Second 20\%, Middle } \\
20 \% \text {, Fourth } \\
20 \% \text {, \& Richest 20\% }\end{array}$ & $\begin{array}{l}\text { Poorest } 20 \%=18.44 \% \\
\text { Second } 20 \%=20 \% \\
\text { Middle } 20 \%=20.63 \% \\
\text { Fourth } 20 \%=20 \%, \& \\
\text { Richest } 20 \%=20.94 \%\end{array}$ \\
\hline
\end{tabular}




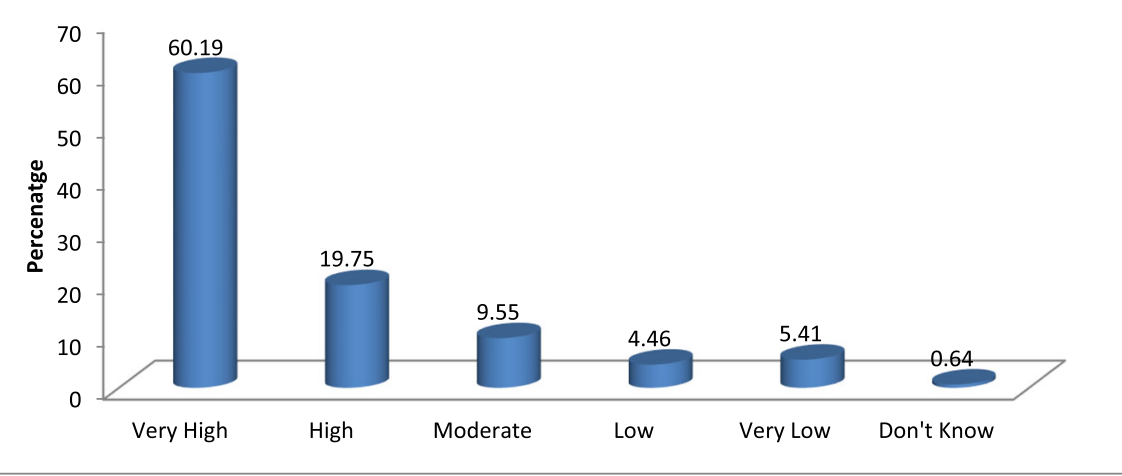

Fig. 1 How would you rate the overall impact of Climate Change in the community

test. Responses from the questionnaire on how households rate the impact of climate change were cross tabulated with their response on the need for finance. The chi-squared test and Spearman's correlation were then performed to measure the strength of the relationship.

A Kruskal-Wallis test was used to determine whether the random sample drawn from either community stochastically dominated the other. The estimated probability value was not significant (see Table 1). This implies that no sample dominated the other. In other words, it tests the hypothesis that several samples are from the same population. The insignificant probability value therefore implies that the samples were not from the same population. This indicates that despite the proximity of Rijau and Fakai, both communities possess different socioeconomic characteristics. This is important as it shows heterogeneity in the respondents, which is good for sample representation.

As a useful adjunct to the Kruskal-Wallis test, nptrend performs the nonparametric test for trends across ordered groups. Thus, we conducted this test using income for households classified by income quintiles. The result yielded a z-score of 17.5 and a probability value that was significant at $1 \%$ and $5 \%$ (see Table 2). This implies that there was a trend in the income of the respondents across the ordered group (i.e., the income quintiles).

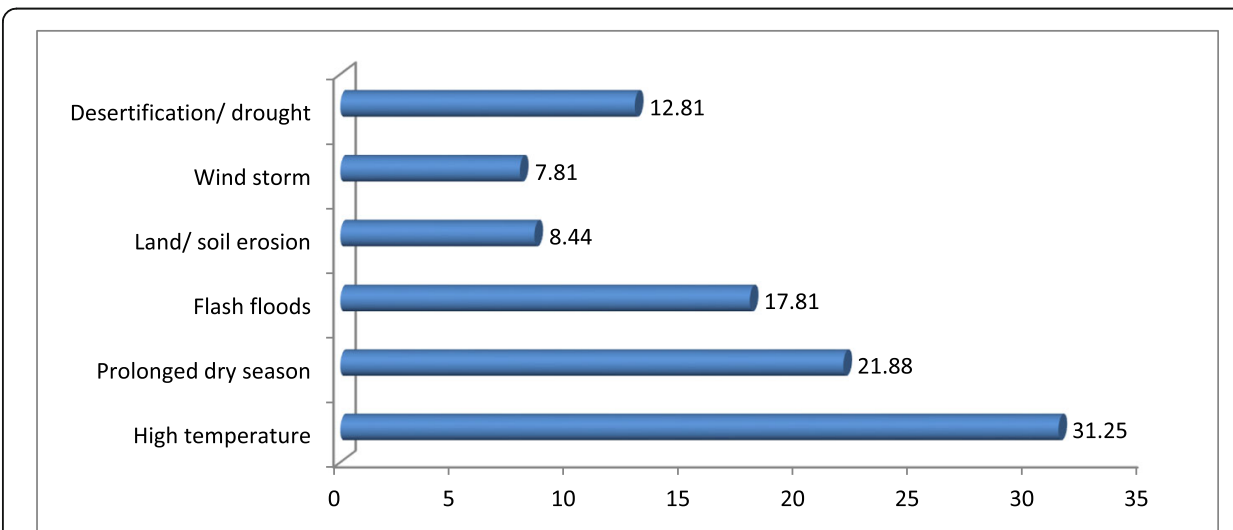

Fig. 2 In what ways is your community affected by the Impact of Climate Change: Response by Proportion (\%) 
Table 4 Descriptive Statistics from Respondents on Financial Access in Rural Northern Nigeria

\begin{tabular}{lc}
\hline & No (\%) \\
\hline Are there financial institution in the community & 6.25 \\
Do you have need for finance to help boost poor farm & 4.06 \\
harvest due to increasing challenge of climate change & \\
Have you borrowed from family and friends in the past & 12.5 \\
12 months & 74.38 \\
Have you borrowed from another private lender in the past & \\
12 months & 80.0 \\
Have you borrowed from a financial institution in the past & 63.75 \\
$\begin{array}{l}12 \text { months } \\
\text { Proportion with Bank Account }\end{array}$ & 77.19 \\
Proportion with access to crop insurance & 63.44 \\
Proportion having benefited from government agricultural & \\
programme & 70.69 \\
Proportion with savings with a financial institution & 33.44 \\
Proportion with membership of savings club & 65.00 \\
Proportion to have benefited from financial literacy programme & 4.06 \\
Proportion who needed finance but had no access &
\end{tabular}

Source: Field Survey, 2014

\section{Results and discussion}

\section{Exposure of rural farm households to climate change}

Descriptive analysis of the field data (see Table 3 ) shows that the maximum annual income of farmers in the selected rural northern communities is 360,000 naira (\$1827.41), while the minimum is 13,000 (\$65.99), with an average of 91,372 naira (\$248.97) per annum. Of this amount, farm income accounts for $77 \%$ while off-farm income accounts for $23 \%$. With a maximum household size of 12 , this yields a per capita income of $\$ 0.42$ a day (maximum), a minimum per capita income of $\$ 0.02$, and an average of $\$ 0.11$. When asked to rate how they perceived their exposure to climate change, $45 \%$ said very high, $33.44 \%$ high, 11.56\% moderate,31\% low, and 4.69\% very low (see Fig. 1).

Figure 1 shows the distribution of the respondents in this regard. Specifically, Fig. 2 shows that increased temperature, prolonged dry seasons, effects of flash floods, and drought were the most typical effects through which rural farm households felt the impact of climate change. These factors are consistent with those identified in Farauta
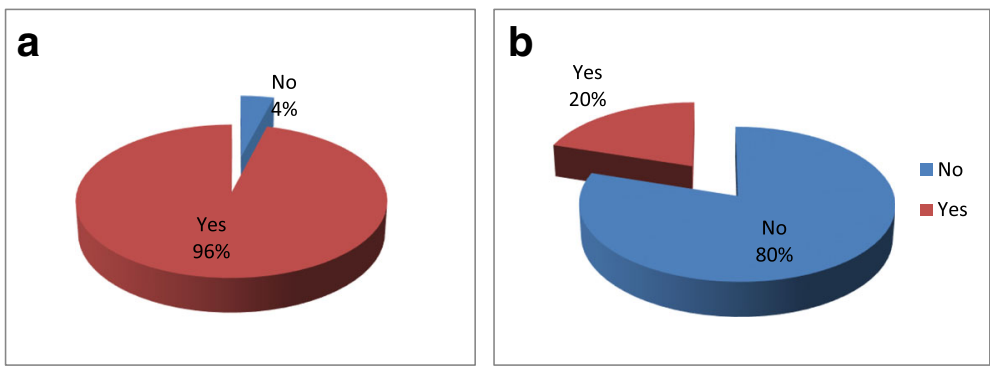

Fig. 3 a: Proportion of Respondents who needed finance but had No access. b: Proportion of Respondent who had actually borrowed from a financial institution 


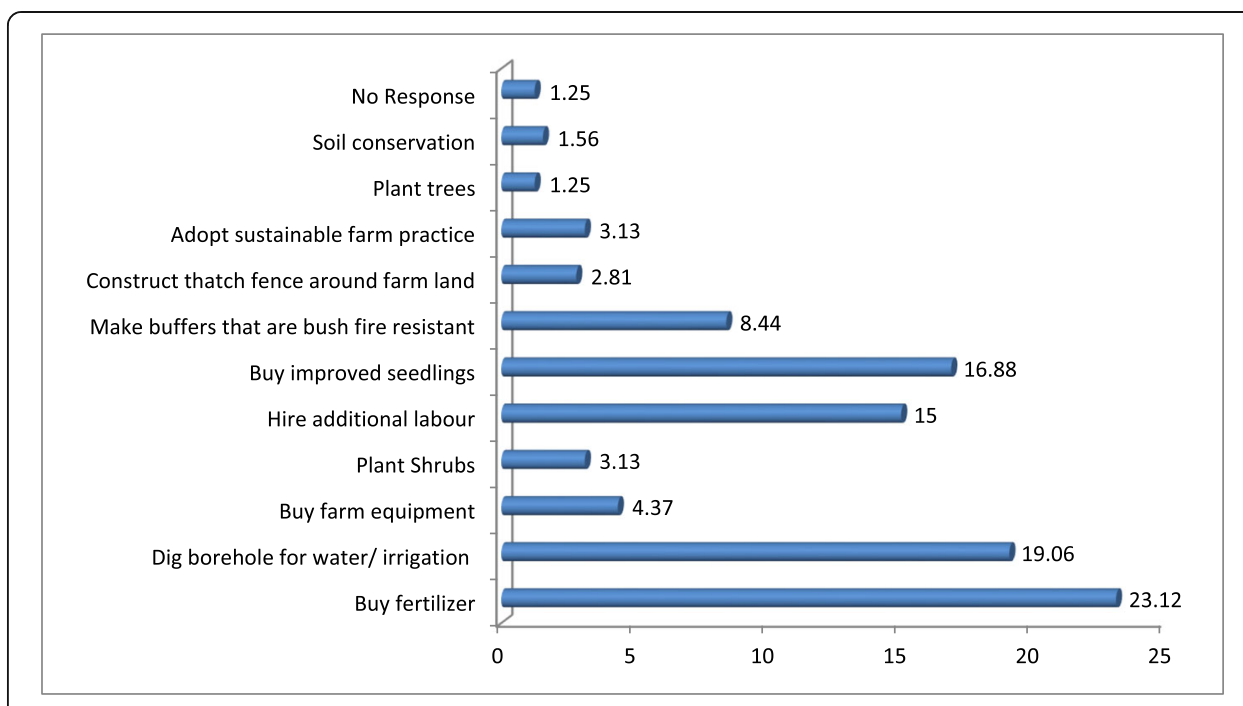

Fig. 4 Purpose for which Credit was sought by Household by Proportion (\%)

et al. (2011). Most of the respondents also rated the negative impact of climate change in their community as very high $(60.19 \%)$ or high $(19.75 \%)$. Since the respondents are mostly farmers, this would directly affect their farming activity, thus constituting a shock to their farm income.

\section{Relationship between the exposure of rural farm households to climate change and the need for financial access as an adaptation strategy}

When asked whether they required financing to help boost poor farm harvests due to the increasing challenges posed by climate change, $95.94 \%$ of respondents said yes while $4.06 \%$ said no (see Table 4 ).

Following Zeller and Sharma (2002), who noted the need to clearly identify households that might have chosen not to borrow money even when they had access to credit and others who wanted to borrow money but had no access, we asked if the respondents had access to financing but chose not to borrow money; $95.94 \%$ said no. This implied that 95.94\% of the respondents needed financing but had no access (se Fig. 3a and b).

With respect to the purpose for which credit was sought, the distribution of the responses (see Fig. 4) showed that most households needed the credit to purchase fertilizers $(23.12 \%)$, dig boreholes for water/irrigation purposes (19.06\%), and buy improved seedlings $(16.88 \%)$. Past government programs in Nigeria focused strongly on improving access to fertilizers, improving access to irrigation, and enhancing farmers' access to improved seedlings. The higher proportion needing access to credit for these same reasons indicates that government programs in this aspect may not reach those that need them the most. By having access to credit, the respondents implied that it would enhance their adaptive capacity as it would help them cope with irrigation issues, access improved seedlings, make buffers that are bush-fire resistant, and adapt sustainable farming practices, among other strategies. How this access would help improve their livelihoods (measured using income) and whether it would benefits those with the lowest income are the topics of the next two sections. 
Table 5 Cross Tabulation of Farmers Responses of How Climate Change Impacts them and why they Need Finance

\begin{tabular}{|c|c|c|c|c|c|c|c|}
\hline \multirow[b]{2}{*}{ Why farmer need finance } & \multicolumn{7}{|c|}{ Farmers rating of how climate change impacts them } \\
\hline & $\begin{array}{l}\text { Very } \\
\text { high }\end{array}$ & high & moderate & low & $\begin{array}{l}\text { Very } \\
\text { low }\end{array}$ & $\begin{array}{l}\text { No } \\
\text { response }\end{array}$ & Total \\
\hline Buy fertilizer(do boost farm harvest) & 74 & 0 & 0 & 0 & 0 & 0 & 74 \\
\hline $\begin{array}{l}\text { Dig borehole for irrigation purpose (to address } \\
\text { drought through irrigation) }\end{array}$ & 61 & 0 & 0 & 0 & 0 & 0 & 61 \\
\hline Buy farm equipment & 0 & 14 & 0 & 0 & 0 & 0 & 14 \\
\hline Plant shrubs & 0 & 0 & 0 & 10 & 0 & 0 & 10 \\
\hline Hire additional labour & 0 & 48 & 0 & 0 & 0 & 0 & 48 \\
\hline Buy improved seedlings (do boost farm harvest) & 54 & 0 & 0 & 0 & 0 & 0 & 54 \\
\hline Make buffers that are bush fire resistant & 0 & 0 & 26 & 0 & 0 & 0 & 26 \\
\hline $\begin{array}{l}\text { Construct thatch fences around farm land to shield } \\
\text { from ruminants }\end{array}$ & 0 & 0 & 0 & 0 & 7 & 0 & 7 \\
\hline Adopt sustainable land management practices & 0 & 0 & 0 & 0 & 10 & 0 & 10 \\
\hline Plant trees & 0 & 0 & 0 & 4 & 0 & 0 & 4 \\
\hline Soil Conservation & 0 & 0 & 4 & 0 & 0 & 0 & 4 \\
\hline No response & 0 & 0 & 0 & 0 & 0 & 2 & 2 \\
\hline Total & 189 & 62 & 30 & 14 & 17 & 2 & 314 \\
\hline
\end{tabular}

Cross tabulating the responses from the questionnaire on how households rate the impact of climate change with their responses pertaining to the need for financing yielded the following chi-squared test and Spearman's correlation results (see Table 5 and Table 6).

The chi-squared test shows an estimated value of 1570 with 55 degrees of freedom, which is significant at the $5 \%$ critical value (see Table 6). This indicates that the hypothesis that there is a significant relationship between the exposure of rural farm households to climate change and their need for financial access is accepted. The Spearman correlation between exposure to climate change and the need for financial access in rural northern Nigeria is $63.9 \%$. The policy implication is that the need to mitigate the adverse effects of climate change on rural farmers increases their need for financing by 63.9\% (see Table 7).

\section{Conclusion and policy implication}

The general conclusion reached in this paper is that rural farmers in selected rural communities in northern Nigeria perceive their exposure to the negative effects of climate change to be very high. This is consistent with findings from smallholder farmers in other communities in developing countries, as shown in the findings of Roco et al. (2015), Ochenje et al. (2016), Munthali et al. (2016), and Arshad et al (2016). For the case of northern Nigeria, as shown in this study, the result from the correlation analysis

Table 6 Chi-Square Test Result

\begin{tabular}{llll}
\hline & Value & df & Asymp. Sig. (2-sided) \\
\hline Pearson Chi-Square & $1570.000^{\mathrm{a}}$ & 55 & .000 \\
Likelihood ratio & 740.406 & 55 & .000 \\
Linear-by-Linear Association & 150.630 & 1 & .000 \\
N of Valid Cases & 314 & & \\
\hline
\end{tabular}


Table 7 Pearson's and Spearman Correlation of How Farmers Perceive their Exposure to Climate Change and Why they Need Finance

\begin{tabular}{lllll}
\hline & Value & Asymp. Std. Error $^{\mathrm{a}}$ & Approx. T $^{\mathrm{b}}$ & Approx. Sig. \\
\hline Interval by Interval Pearson's R & .694 & .032 & 17.013 & $.000^{\mathrm{c}}$ \\
Ordinal by Ordinal Spearman Correlation & .639 & .039 & 14.655 & $.000^{\mathrm{c}}$ \\
N of Valid Cases & 314 & & & \\
\hline
\end{tabular}

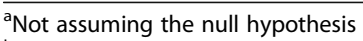

busing the asymptotic standard error assuming the null hypothesis

'Based on normal approximation

shows a $63 \%$ association between exposure to climate change and the need for finance, and $96 \%$ of those seeking credit to mitigate these impacts would be unable to do so. The paper therefore provides the following recommendations: 1) The Central Bank of Nigeria should ensure that microfinance institutions refocus their products/services to those who need them the most to enhance access to financial resources and enable farmers to build resilience that will maximize post-harvest gains. 2) Considering that climate change is a global phenomenon with local effects, perhaps the international community could support lending to smallholder farmers through central banks by insuring the loans that banks lend to farmers towards financing climate change adaptation strategies.

\section{Acknowledgements}

The Author appreciates the German Federal Ministry of Education (BMBF) for funding this research through the WASCAL Graduate Programme on Climate Change Economics and the Universite Cheikh Anta Diop, Dakar - Senegal, within $2013-2016$. As such, the author appreciates Prof. A. Aly Mbaye (mbayealy93@yahoo.fr) the Director of the WASCAL programme at the FASEG, Universite Cheikh Anta Diop for his contributions as the thesis advisor.

\section{Funding}

This paper benefits from the Graduate Research Programme in Climate Change Economics fund provided by the German Federal Ministry of Education (BMBF) in collaboration with the Zentrum für Entwicklungsforschung (ZEF)/ Centre for Development Research, Department for Economic and Technological, Universität Bonn, Bonn - Germany under the West African Science Service Center on Climate Change and Adapted Land Use (WASCAL) hosted at the Universite Cheikh Anta Diop de Dakar, Senegal.

\section{Availability of data and materials}

The primary data collected and used for this study was funded under the German Federal Ministry of Education (BMBF) Funds for Climate Change Economics under the WASCAL (West African Science Service Centre on Climate Change and Adapted Land Use) Graduate Research Programme for 2013-2016 at the Universite Cheikh Anta Diop, de Dakar - Senegal. The data set is hosted on the WASCAL Geo portal available on the link: https://wascal-dataportal.org/ geonetwork/apps/search/

\section{Authors' contributions}

This paper is an extract from the Ph.D thesis of TWA at the Universite Cheikh Anta Diop de Dakar, Senegal, funded under the BMBFMASCAL Graduate Research Programme in Climate Change Economics. Dr. WF contributed in the aspect of conceptualizing financial access as a climate change adaptation strategy, and in guiding the analysis of the primary data while TWA served as a visiting junior researcher at the WASCAL Competence Centre at Ouagadougou. Burkina Faso, where Dr. William Fonta served as WASCAL Senior Economist. All authors read and approved the final manuscript.

\section{Ethics approval and consent to participate}

Field data used for the study were collected with utmost neutrality. It also does not mention names or personal data of the respondents as such, violates no ethical consideration or participation requirement.

\section{Consent for publication}

This paper is an offshoot of the authors PhD thesis at the Universite Cheikh Anta Diop (UCAD) funded under the WASCAL Graduate Research Programme on Climate Change Economics initiative of the German Federal Ministry of Education (BMBF) in collaboration with the Centre for Development Research (ZEF) at the University of Bonn, Germany. The author is expected to publish findings from this study hence, consented to publish.

\section{Competing interests}

The authors declare that they have no competing interests.

\section{Author details}

${ }^{1}$ National Institute for Legislative \& Democratic Studies (NILDS), No.1 River Niger Street, Maitama, Abuja, Nigeria.

${ }^{2}$ WASCAL Competence Centre, Ouagadoudou, Burkina Faso. 
Received: 8 September 2017 Accepted: 4 June 2018

Published online: 13 June 2018

\section{References}

Agrawala S, Carraro M (2010) Assessing the role of microfinance in fostering adaptation to climate change, Organisation for Economic Co-operation and Development (OECD) Environmental Working Paper No 15, 2010. https://doi.org/10.1787/5kmlcz34fg9v-en

Agwu J, Okhimamhe AA (2009) Gender and climate change in Nigeria: A study of four communities in North-Central and South-Eastern Nigeria' Heinrich Böll Stiftung (HBS) Publication

Aiello F (2009) Experiences with traditional compensatory finance schemes and lessons from FLEX' Department of Economics and Statistics Working Paper 12. University of Calabria, Calabria

Akter S, Fatema N (2011) The role of microcredit and micro insurance in coping with Natural Hazard Risks. A paper presented at the 18th Annual Conference of the European Association of Environmental and Resource Economists (EAERE), 2nd July, Rome

Allison PD (1978) Measures of inequality. Am Sociol Rev 43(6):865-880

Amuedo-Dorantes C, Pozo S (2011) Remittances and income smoothing. The Institute for the Study of Labor (IZA) Discussion Paper Series No 5568 (March)

Ardic OP, Heimann M, Mylenko N (2011) Access to financial services and the financial inclusion agenda around the World: A Cross-Country analysis with a New Data Set. The World Bank Financial and Private Sector Development Consultative Group to Assist the Poor, Policy Research Working Paper 5537 (January)

Arshad M, Kächele H, Krupnik TJ, Amjath-Babu TS, Aravindakshan S (2016) Climate variability, farmland value, and farmers' perceptions of climate change: implications for adaptation in rural Pakistan. Int I Sust Dev World Ecol 24(6):532-544

Ayers JM, Huq S (2009) Supporting adaptation to climate change: what role for official development assistance? Dev Policy Rev 27(6):675-692

Baumüller H, Ladenburger C, von Braun J (2011) Innovative business approaches for the reduction of extreme poverty and marginality, Centre for Development Research (ZEF) Working Paper Series 80 (June). University of Bonn, Germany

Beck T, Demirgüç-Kunt A, Levine R (2004) Finance, inequality and poverty: Cross-country evidence, Policy Research Working Paper 3338. World Bank, Washington, DC

Beck T, Demirgüç-Kunt A, Levine R (2007) Finance, inequality, and the poor. J Econ Growth 12(1):27-49

Beck T, Levine R, Loayza N (2000) Finance and the sources of growth. J Financ Econ 58:261-300

BNRCC (2011) National adaptation strategy and plan of action on climate change for Nigeria (NASPA-CCN). A Publication of the Building Nigeria's Response to Climate Change (BNRCC) Project, for the Federal Ministry of Environment Special Climate Change Unit

Botzen WJW, van den Bergh JCJM (2008) Insurance against climate change and flooding in the Netherlands: present, future and comparison with other countries. Risk Anal 28(2):413-426

Caskey J, Duran CR, Solo TM (2006) The urban unbanked in Mexico and the United States, Policy research working paper 3835. World Bank, Washington, DC

CBN (2012) Nigeria's national financial inclusion strategy. Publication of the Central Bank of Nigeria (CBN), Abuja

CCAA (2010) Approaching climate change adaptation as a means to reduce poverty. Climate Change Adaptation in Africa (CCAA) Program 2010-11 Annual Report: Publication by International Development Research Centre (IDRC) and UK Department for International Development (DFID)

Chaudhuri S, Jalan J, Suryahadi A (2002) Assessing household vulnerability to poverty: A methodology and estimates for Indonesia, Columbia University Department of Economics Discussion Paper No. 0102-52. Columbia University, New York

Christiaensen L, Subbarao K (2001) Towards an understanding of vulnerability in rural Kenya. World Bank, Washington, D.C

Collier BL (2013) Financial inclusion and natural disasters. Doctoral Dissertation, University of Kentucky, Department of Agricultural Economics, (Dissertation Supervisors: Jerry R. Skees, Michael Reed and Mario Miranda), Lexington

Cull R, Ehrbeck T, Holle N (2014) Financial inclusion and development: Recent impact evidence. Focus Note 92. Consultative Group to Assist the Poor (CGAP), Washington, D.C

Czura K (2011) Informal finance as coping mechanisms in dealing with floods - evidence from North India. University meets microfinance (UMM) report on Rural Finance \& Savings (6th University meets microfinance workshop University of Groningen, 17-18 June)

De Sherbinin A, vanWey L, McSweeney R, Aggarwal A, Barbieri S, Henry L, Hunter M, Twine W (2008) Rural households demographics, livelihoods and the environment. Glob Environ Change 18(1):38-53

Demirguc-Kunt A, Klapper L, Singer D, van Oudheusden P (2015) The Global Findex Database 2014: Measuring financial inclusion around the world. World Bank Group, Policy Research Working Paper 7255 (April)

Demirgüç-Kunt A, Levine R (2008) Finance, financial sector policies, and long-run growth. Policy Research Working Paper WPS4469. the World Bank, Washington, DC

Demirgüç-Kunt A, Maksimovic V (1998) Law, finance, and firm growth. J Financ 53:2107-2137

Diagne A, Zeller M (2001) Access to credit and its impact on welfare in Malawi' International Food Policy Research Institute (IFPRI) Research Report 116 (March)

Draper P, Grant C, kingombe C, te Velde DW (2011) The G20 and African development. Oversea development institute (ODI) and south African Institute of International Affairs (SAllA) publication (March)

Ejiogu AO, Ejiogu BC (2010) Climate change compliant microfinance delivery in Nigeria. J Account Tax 2(3):46-50

Ellis K, Lemma A, Rud JP (2010) Financial inclusion, household investment and growth in Kenya and Tanzania. Oversea Development Institute (ODI) project briefing 43

Elum ZA, Modise DM, Marr A (2017) Farmer's perception of climate change and responsive Startegies in three selected provinces of South Africa. Climate Risk Manag 16:246-257

Eriksen EH, Klein RJT, Ulsrud L, Næess O, O'Brien L (2007) Climate change adaptation and poverty reduction: Key interactions and critical measures. Report prepared for the Norwegian Agency for Development Cooperation (Norad) 
Farauta BK, Idrisa YL, Egbule CL, Agu VC (2011) Farmers' perceptions of climate change and adaptation strategies in Northern Nigeria: An empirical assessment' African Technology Policy Studies Network Research Paper | No. 15

Fonta WM, Onyukwu OE, Nwosu EO (2011) International remittance inflows and household welfare: empirical evidence from Nigeria. Research Journal of Finance and Accounting 2(3):140-150

Forcella D (2013) Microfinance and adaptation to climate change. 10th University meets microfinance (UMM) workshop report, Frankfurt, 5th July

Grammy A, Assane D (2006) The poverty growth inequality triangle hypothesis: an empirical examination. J Policy Model, p 1-12. http://www.econmodels.com/upload7282/a77f04149bbad14085ce30ac170e7da0.pdf

Greenwood J, Jovanovic B (1990) Financial development, growth, and the distribution of income. J Polit Econ 98:1076-1107

Gross DM (2002) Financial intermediation: a contributing factor to economic growth and employment, Social finance working paper 27. ILO, Geneva

Hess U (2003) Innovative financial services for rural India: Monsoon-indexed lending and insurance for smallholders, Working Paper No. 9, Agriculture and Rural Development Department. The World Bank, Washington, DC

Hoddinott J, Quisumbing A (2003) Methods for microeconometric risk and vulnerability assessments. Discussion Paper Series of the Social Protection Unit, The World Bank No. No. 0324 (December)

IFAD (2014) Promoting the resilience of poor rural households. International Fund for Agricultural Development (IFAD) Post-2015 Policy Brief 4

IISD (1995) Report of the World Summit for Social Development: 6-12 March 1995' Published by the International Institute for Sustainable Development (IISD) 10 (44): 1-10

Kim JY (2013) Within our grasp: a world free of poverty. World Bank Group president speech at Georgetown University as prepared for delivery, April 2

King R, Levine R (1993) Finance, entrepreneurship and growth: theory and evidence. J Monet Econ 32:513-542

Klapper L, Laeven L, Rajan R (2006) Entry regulation as barrier to entrepreneurship. J Financ Econ 82:591-629

Krol A, Miedema JM (2009) Measuring income inequality: An Exploratory Review' A Publication of Region of Waterloo Public No 431158

Kwanashie M, Ajilima I, Garba AG (1998) The Nigerian economy: response of agriculture to adjustment policies. African economic research consortium (AERC) Research Paper 78 (March)

Levine R (2005) Finance and growth: theory and evidence. In: Aghion P, Durlauf SN (eds) Handbook of economic growth, vol 1A, pp 865-934

Ligon E, Schechter L (2003) Measuring vulnerability. Econ J 113:C95-C102

MeheRette E (2009) Innovations in insuring the poor: providing weather index and indemnity insurance in Ethiopia. International food policy research institute (IFPRI) 2020 vision for food, agriculture, and the environment, Focus 17 Brief 8 (December)

Munthali CK, Kasulo V, Matamula S (2016) Smallholder farmers perception on climate change in Rumphi District, Malawi. J Agric Ext Rural Dev 8(10):202-210

Nelson W, Agbey SND (2005) Linkages between poverty and climate change: adaptation for livelihood of the poor in Ghana. Technical Paper of the Netherlands Climate Assistance Programme

Ochenje I.M., Ritho C.N., Guthiga P M., Mbatia O.L.E (2016), 'Assessment of Farmers' Perception to the Effects of Climate Change on Water Resources at Farm Level: The Case of Kakamega County, Kenya' presented at the 5 th International Conference of the African Association of Agricultural Economists, September 23-26, 2016, Addis Ababa, Ethiopia

Pettengell C (2010) Climate change adaptation enabling people living in poverty to adapt. Oxfam Res Rep, p 1-48. https://policy-practice.oxfam.org.uk/publications/climate-change-adaptation-enabling-people-living-inpoverty-toadapt-111978

Richter P (2011) Empowering rural communities through financial inclusion rural policy briefs. Rural Finance Team, Social Finance Programme; International Labour Organisation (ILO), Geneva

Roco L, Engler A, Bravo-Ureta BE, Jara-Rojas R (2015) Farmers' perception of climate change in Mediterranean Chile. Reg Environ Chang 15:867-879

Skees J, Collier B (2008) The potential of weather index insurance for spurring a green revolution in Africa. A Publication of GlobalAgRisk, Inc., Lexington

Skees JR, Goes A, Sullivan C, Carpenter R, Miranda M, Barnett B (2006) Index insurance for weather risk in low-income countries. A Publication of GlobalAgRisk, Inc., Lexington

Sorensen C (2000) Social capital and rural development: A discussion of issues. World Bank Social Capital Initiative Working Paper No. 10

Tesliuc E, Lindert K (2002) Vulnerability: a quantitative and qualitative assessment. Guatemala poverty assessment program. World Bank, Washington, D.C.

UNSGSA (2013) Thoughts on financial inclusion in post-2015 development. United Nations Secretary Generals Special Advocate for Inclusive Finance for Development (UNSGSA) Report

von Braun J (2002) Forward in the book, Triangle of microfinance: Financial sustainability, outreach, andimpact. Zeller M, Meyer RL (ed) (page xix - xx). The Johns Hopkins University Press, Baltimore

WFP and IFAD (2011) Weather index-based insurance in agricultural development: A technical guide' World Food Programme (WFP) and the International Fund for Agricultural Development (IFAD) Publication (November)

World Bank (2012) Financial innovations for social and climate resilience: establishing an evidence base' Social Resilience \& Climate Change study. World Bank Publication, Washington

World Social Science Report (2013) Changing Global Environments A Publication of UNESCO (United Nation Educational, Scientific and Cultural Organization) and ISSC (International Social Science Council)

Yang D, Choi HJ (2007) Are remittances insurance? Evidence from rainfall shocks in the Philippines. World Bank Econ Rev 21(2):219-248

Zeller M, Sharma M (2002) Access to and demand for financial services by the rural poor: A multi-country synthesis' in the triangle of microfinance: Financial sustainability, outreach, and impact. Zeller M, Meyer RL (ed). The Johns Hopkins University Press, Baltimore, pp 19-45 